\title{
Maallikkosaarnan retoriikkaa: uskonnollinen puhe yhteisön rakentajana
}

\author{
Elina Siltala \& Saila Poutiainen
}

\section{Tiivistelmä}

Suomalaista saarnapuhetta on tutkittu melko runsaasti, myös retorisesta näkökulmasta, mutta maallikkosaarnojen tutkimus on vähäistä. Aiemmat tutkimukset kirkkosaarnoista ja maallikkosaarnoista kuitenkin osoittavat, että yhteisistä sisällöistä huolimatta ne edustavat melko erilaisia puhetyyppejä. Herätysliikesaarnaa leimaavat puheen spontaanius, kohdistaminen kirkkosaarnaa selvärajaisemmalle yhteisölle sekä saarnapuheen merkittävä rooli herätysliikeyhteisön viestintäkulttuurissa ja koko toiminnassa.

Retorisen analyysin lähtökohtana käytettiin puhe-esitystä monesta eri näkökulmasta lähestyvää mallia, joka pohjautuu yhdysvaltalaisen George A. Kennedyn (1984) Raamatun tekstien tutkimuksessa käyttämään kehikkoon. Tässä sovellettua menetelmää ei siis ole alun perin luotu puhuttujen, äänitettyjen tai havainnoitujen saarnojen analyysia varten. Mallissa lähdetään liikkeelle retorisen yksikön määrittelystä ja edetään retorisen tilanteen ja sen asettamien vaatimusten kautta puheaineksen jäsentelyyn ja lopulta siihen, miten retorinen yksikkö on kyennyt täyttämään tilanteen luomat vaatimukset.

Tutkimusaineisto koostui viidestä esikoislestadiolaisen herätysliikkeen maallikkosaarnasta. Saarnat litteroitiin ja niistä poimittiin puhujien käyttämät retoriset tehokeinot, joista yleisimmin esiintyvien käyttötapoja tarkasteltiin lähemmin. Saarnojen retorista tilannetta, rakennetta sekä maallikkosaarnaa puhetyyppinä analysoitaessa tuloksia täydennettiin havaintojen pohjalta tehdyillä tulkinnoilla.

Saarnat etenivät assosiatiivisesti, ja niissä oli runsaasti puhujan tehokeinoja: Raamatusta lainattua kuvakieltä, retorisia kysymyksiä, vastakkainasetteluja ja toisteisuutta. Retorisen analyysin perusteella saarnoista piirtyi kuva omalle puheyhteisölle suunnatuista, yhteisön perinteitä noudattavasta puheesta, jolla on monia funktioita herätysliikkeen toiminnassa. Saarnat toimivat opetuksen sekä herätysliikeyhteisön identiteetin rakentamisen ja ylläpitämisen välineinä. Niiden avulla luodaan turvallisuuden tunnetta sekä rohkaistaan kuulijoita.

Asiasanat: herätysliikkeet, lestadiolaisuus, retoriikka, saarnaajat, saarnat 


\section{Johdanto}

Suomen evankelis-luterilaisen kirkon sisällä toimivat herätysliikkeet eli kirkon toimintaa tai opetusta uudistamaan pyrkivät liikkeet ovat vuosikymmenien kuluessa muuttuneet, mutta eivät suinkaan sammuneet. Herätysliikkeiden elinvoimaisuudesta kertovat esimerkiksi liikkeiden omat hengelliset kesäjuhlat, jotka keräävät arviolta 200000 osallistujaa vuosittain. Tässä artikkelissa kuvataan yhden herätysliikkeen, esikoislestadiolaisuuden, seuratilanteessa kuultuja saarnoja ja pohditaan sitä, miten yhteisön arvot ja uskomukset näkyvät ja kuinka niitä ylläpidetään saarnapuheessa. Aiemmin esikoislestadiolaisuutta on tarkasteltu jonkin verran esimerkiksi kirkkohistoriallisesta, teologisesta ja kielitieteellisestä näkökulmasta (ks. esim. Ihonen 1997, 2001; Raittila 1984; Talonen 1993).

Esikoislestadiolaisuus on runsaat sata vuotta toiminut liike ja noin kymmenen tuhannen ihmisen tiivis yhteisö. Liikkeen voidaan sanoa muodostaneen oman pienoiskulttuurinsa, jossa on omanlaisensa säännöt ja odotukset niin puhujille kuin kuulijoillekin (Kinnunen 2004, 31). Esikoislestadiolaisia elää ja toimii ympäri Suomea, erityisesti Etelä-Suomessa. Esikoislestadiolainen liike, kuten muutkin herätysliikkeet, toimii maallikkojohtoisesti. Viikoittaiset paikkakuntakohtaiset seurat ovat toiminnan ydintä, lisäksi kullakin paikkakunnalla järjestetään 3-4 kertaa vuodessa valtakunnalliset seurat. Sekä oman asuinpaikkakunnan että valtakunnalliset seuratilaisuudet ovat merkittäviä sosiaalisia tapahtumia, ja monen esikoislestadiolaisen sosiaalinen verkosto muodostuukin paljolti muista herätysliikkeen jäsenistä.

Seuratilaisuuden kesto on yleensä 1,5-2,5 tuntia. Seurojen muoto on kehittynyt herätysliikkeen alkuaikojen epämuodollisten rukoushetkien perinteestä (Raittila 1976, 223). Nykyisellään seuroissa on alku- ja loppurukoukset, yhden saarnaajan lukema Laestadiuksen saarna sekä toisen saarnaajan pitämä spontaani saarna eli raamatunselityspuhe, joka kestää yleensä noin tunnin. Lisäksi lauletaan 4-5 virttä, jotka toimivat siirtyminä tekstiosioiden välillä. (Ks. myös Raittila 1976, 224.) Seurojen jälkeen on useimmiten tarjolla kahvit, joiden ääreen jäädään jutustelemaan. Seuroihin osallistuu enimmäkseen seurakunnan aktiivijäseniä, joko yhden paikkakunnan seurakuntalaisia tai valtakunnallisissa seuratapahtumissa laajemmalta alueelta tulleita. Osallistujamäärät vaihtelevat pienimpien paikkakuntien muutamasta ihmisestä isoimpien valtakunnallisten seurojen tuhansiin osallistujiin. Yhteisön jäsenyys näkyy seuratilaisuuksissa esimerkiksi perinteisenä pukeutumisena: naiset pukeutuvat yleensä hameeseen ja suurin osa solmii tilaisuuden ajaksi huivin päähänsä, koruja ja runsasta meikkiä ei juuri näe. Miehillä on harvoin pitkiä hiuksia, vaatetus on yleensä siisti, tosin pukukoodi on melko vapaa. Yhteisön jäsenet hallitsevat myös tilanteen käyttäytymiskoodin, kuten tervehdykset "Jumalan terve(ttä)" tavatessa ja "Jumalan rauhaa" erotessa. Tilaisuudet ovat kaikille avoimia ja siis julkisia, mutta tiiviin 
tuttujen yhteisön ja jaettujen pukeutumisnormien vuoksi ulkoryhmäläinen eli herätysliikkeen perinnettä tuntematon erottuu joukosta.

Saarna on seuratilaisuuden kestoltaan pisin yksittäinen elementti ja keskeinen myös siitä syystä, että se on ainoa ainutkertainen, hetkellinen ja juuri kyseistä tilaisuutta varten luotu teksti. Seuroissa saarnaavat seurakuntalaisten joukosta valitut maallikkopuhujat. Saarnavuoro on yleensä ennalta puhujan tiedossa, joskus vuorosta sovitaan vasta seuratilaisuuden alussa. Ottaen huomioon että suomalaisia saarnaajia on kaikkiaan hieman toista sataa ja heistä valtakunnallisissa seuratilaisuuksissa saarnaavia niin kutsuttuja lähetysmiehiä vain 18 , voi yksittäisenkin puhujan persoonallisuus ja rooli herätysliikkeen toiminnassa olla merkittävä.

Evankelis-luterilaisen kirkon papeille suunnatuissa oppaissa kehotetaan saarnojen huolelliseen valmisteluun, jopa kahden viikon mittaiseen kypsyttelyyn sunnuntaisaarnaa varten (esim. Lampinen 1990, 145, ks. myös Antola 2009), kun taas herätysliikesaarnojen spontaanius on eräänlainen kirjoittamaton sääntö, jonka olemassaolon syitä esimerkiksi Blom (2001) on hakenut niin opista kuin perinteestäkin. Itsekin esikoislestadiolaisen liikkeen saarnaajana toiminut teologi Risto Blom $(2001,47,128)$ pohtii tutkimuksessaan syitä spontaanin saarnan perinteelle: jos saarna olisi kirjoitettu etukäteen, puheen ei katsottaisi olevan Pyhästä Hengestä lähtöisin eikä siten elävää julistusta. Samaa käsitystä esiintyy Blomin mukaan runsaasti myös muissa kristillisissä yhteisöissä. Suojasen $(1973,150)$ tulkinnan mukaan rukoilevaisten seuroissa saarnan valmistelua ei katsottu hyväksi, sillä "saarnaaja käsitetään instrumentiksi ja transsendentaalisten voimien objektiksi, joka tulkitsee 'tässä ja nyt' saatua aktuaalia sanottavaa Jumalalta". Tämän mukaan puheen kirjoittaminen nähtäisiin siis liiallisena ihmisen väliintulona asiassa, jonka pitäisi olla Jumalan käsissä.

Suomalainen maallikkosaarnaa ja -saarnaajuutta käsittelevä kirjallisuus on hyvin vähäistä, lähinnä tutkimusta on tehnyt etnologi, folkloristi ja uskontoantropologi Päivikki Suojanen (nyk. Antola) 1970- ja 1980-luvuilla. Kirkkosaarnoja on eritelty hieman runsaammin, mutta kuten Suojanen $(1973,148)$ toteaa, herätysliikkeiden spontaanin saarnan uskonto- ja kielitieteelliset ominaisuudet erottavat sen selvästi kirkkosaarnasta, sen sisällöstä ja tyylistä.

Tämän tutkimuksen aineistoksi on kerätty viiden esikoislestadiolaisen herätysliikkeen saarnaajan saarna vuosilta 1998-2001. Monissa rukoushuoneissa kaikki niissä pidetyt saarnat taltioidaan ja äänitteet ovat jonkin aikaa vapaasti saatavilla omakustannushintaan. Pelkästään valtakunnallisista seuratilaisuuksista kertyy vuosittain 300-400 saarnaa, joten materiaalia saarna-aineistoksi olisi runsaasti. Analysoidut viisi saarnaa poimittiin yksityishenkilöiden hankkimista äänitekokoelmista. Pattonin $(2002,244)$ määrittelemä aineiston valinta helppouden tai kätevyyden perusteella (convenience sampling) kuvannee otantamenetelmäämme. Saarnat valittiin sattumanvaraisesti mutta rajatusta joukosta. Analysoitavaksi valittiin vain 1) kokeneiden, vähintään kymmenen vuotta 
saarnaajan tehtävissä toimineiden puhujien saarnoja, jotka on 2) pidetty suuren paikkakunnan valtakunnallisessa seuratilaisuudessa. Toisin sanoen tutkimukseen poimitut saarnat rajattiin sellaisiin saarnatilanteisiin, joissa kokeneet lähetysmiehet saarnasivat paikalle olleille sadoille kuulijoille. Saarnat on litteroitu sanatarkasti ja analysoitavana on ollut näin 32 liuskaa 1-rivivälillä kirjoitettua tekstiä. Havainnointia ei varsinaisesti käytetty tutkimusvälineenä, mutta toinen kirjoittajista on yhteisön jäsen, jolloin saarnojen erittelyn tukena toimi myös yhteisön toimintatapojen ja seuratilanteen tuntemus.

Tutkimuksessa kuvataan retorisen analyysin keinoin esikoislestadiolaisen viestintäyhteisön kulttuurista viestintää (ks. esim. Carbaugh 1990). Määrittelemme esikoislestadiolaiset viestintäyhteisöksi, jonka jäsenillä on viestinnässään ja metaviestinnässään ilmitulevia jaettuja uskomuksia ja arvoja viestinnästä, ihmisenä olemisesta ja sosiaalisista suhteista. Kun esikoislestadiolaisten seurojen puhuja olettaa yleisönsä tunnistavan ja hyväksyvän puheidensa aiheet, sanavalinnat, viestinnän muodot (esimerkiksi noin tunnin mittaisen polveilevan monologin eli saarnan), retoriset tehokeinot, puheen tavoitteen ja argumenttien perusteet, hän puhuu tietylle viestintäyhteisölle (ks. Carbaugh \& Wolf 1999). Retorisen analyysin avulla emme pelkästään erittele saarnapuheen retorisia piirteitä, vaan pyrimme tunnistamaan ja kuvaamaan piirteitä viestintäyhteisön uskomuksista ja arvoista. Analysoitujen piirteiden osalta aineiston saarnat osoittautuivat hyvin samankaltaisiksi keskenään.

Retorisen analyysin lähtökohtana on käytetty puhe-esitystä monesta eri näkökulmasta lähestyvää mallia, joka pohjautuu yhdysvaltalaisen George A. Kennedyn (1984) Raamatun tekstien tutkimuksessa käyttämään kehikkoon. Sovellamme siis menetelmää, jota ei ole alun perin luotu puhuttujen, äänitettyjen tai havainnoitujen saarnojen analyysia varten. Kennedy $(1984,33)$ on koonnut yhteen keskeisimmät antiikin retoriikan käsitteet ja muokannut näitä käsitteitä puheen opettamisen välineistä sen analysoinnin työkaluiksi. Kennedyn mallissa lähdetään liikkeelle retorisen yksikön määrittelystä ja edetään retorisen tilanteen ja sen asettamien vaatimusten kautta puheaineksen jäsentelyyn ja lopulta siihen, miten retorinen yksikkö on kyennyt täyttämään tilanteen luomat vaatimukset.

Kennedy (1984, 33-34) toteaa yksittäisen, julkisen puheen, jolla on selkeästi erotettavat alku, keskikohta ja loppu, helposti hahmotettavaksi retoriseksi yksiköksi. Retorinen yksikkö voi olla kokonainen puhe tai teksti, sen osa tai laajempi kokonaisuus. Kennedyn mallin mukainen retorisen yksikön määrittely laajemmasta kokonaisuudesta ei tässä ole tarpeen, sillä yksittäinen puhe on aina selkeä retorinen yksikkö. Määrittelemme siis analyysissamme saarnapuheen retoriseksi yksiköksi ja keskitymme tarkastelemaan retorista tilannetta ja saarnan roolia siinä.

Kennedy $(1984,35)$ määrittelee Lloyd F. Bitzeriä $(1968,4-6)$ lainaten retorisen tilanteen tekijöiksi ajan ja paikan lisäksi ne henkilöt, tapahtumat, tavoitteet ja suhteet, jotka vaikuttavat siihen, mitä sanotaan ja miksi. Puheen yleisö 
tai yleisöt ovat olennainen osa retorisen tilanteen ymmärtämistä. Yleisö ja sen ennakkokäsitykset, asenteet ja suhtautuminen puhujaan ja aiheeseen asettavat haasteensa puhujalle ja vaikuttavat puheen sisältöön ja muotoon. Vaikka kohdeyleisö ei aina selvästi olisikaan esillä puheessa, siitä on löydettävissä puhujan asemoituminen yleisöönsä ja aiheeseensa nähden (Leach 2000, 213). Retorisen tilanteen pohdinta tuo esiin sosiaalisen näkökulman tekstiin, mikä on KakkuriKnuuttilan $(1998,235)$ mukaan yksi keskeisimmistä retorisen analyysin arvoista pelkkään argumentoinnin arviointiin nähden. Analyysissamme keskitymme retorisen tilanteen osalta kuvaamaan saarnapuheen kontekstia eli seuratilannetta.

Kennedyn $(1984,36)$ mukaan retoriseen tilanteeseen voi liittyä myös retorinen ongelma, jonka voi aiheuttaa yleisön ennakkoluuloisuus, puhujan aseman heikkous tai puheena olevan asian vieraus tai monimutkaisuus. Joidenkin herätysliikkeiden saarnoissa tavoitteena on tarjota aivan uusi ajattelutapa omaksuttavaksi, ja saarnojen retorinen ongelma ei edes ole ratkaistavissa, koska kuulijoita herätellään ja ohjataan jatkuvaan muutokseen (Hietanen 2009). Saarnatilanteissa varsinaista retorista ongelmaa ei usein kuitenkaan ole, sillä puhumaan kutsuttu saarnaaja ei yleensä joudu kohtaamaan kielteisesti asennoitunutta kuulijakuntaa. Suojanen $(1988,52)$ toteaakin herätysliikkeiden seuratilaisuuksien viestinnästä, että niiden "luonne ajaa vihamieliset tai välinpitämättömät pois." Esikoislestadiolainen yleisö on tottunut seuratilaisuuksien muotoon ja antaa puhujalle ajan ja tilan pitkään ja polveilevaan puheeseen. Myös puheen sisällöt ovat yleisölle tuttuja ja odotettuja.

Aineiston jäsentelyn ja retoristen erityispiirteiden sekä kauempaa katsoen puheen ja sen tehokeinojen funktioiden tarkastelu kontekstissaan muodostavat analyysin loppuosan. Tässä saarnapuheiden retoriikan tarkastelu etenee siis suuremmista kokonaisuuksista puheen yksityiskohtiin ja etääntyy lopuksi pohtimaan aiempia analyysin kerroksia suhteessa toisiinsa.

Tarkastelemme seuraavassa esikoislestadiolaisten saarnojen retoriikkaa soveltaen Kennedyn mallia puhuttuihin saarnoihin sekä pohdimme retoriikassa ilmeneviä kulttuurisia arvostuksia ja uskomuksia. Etenemme Kennedyn mallin mukaisessa järjestyksessä ja pysähdymme pohtimaan erityisesti saarnatilannetta ja retorisia tehokeinoja.

\section{Maallikkosaarnojen retoriset piirteet \\ Seurat retorisena tilanteena}

Parituntisessa seuratilanteessa saarnapuhe on ympäröity muilla sanaelementeillä, joiden sisältö kertaa samansuuntaisia viestejä saarnan kanssa. Nämä elementit antavat kulloisellekin puhujalle runsaasti mahdollisuuksia viittauksiin sekä aineksia rakentaa assosiaatioin etenevää puhettaan. Virret, rukoukset, Raamatun tekstit ja Laestadiuksen tai Lutherin saarnat ovat myös yhteisön hyväksymiä ja tunnustamia tekstejä, joiden kanssa samassa linjassa pysyttelemällä 
saarnaajat saavat perinteestä ja auktoriteeteista tukea argumentoinnilleen. Kaikissa aineiston saarnoissa esiintyi yhdestä viiteen viittausta saman seuratilaisuuden aikana kuultuun muuhun kuin Raamatun tekstiin. Useimmiten viittaukset kohdistuivat ennen saarnapuhetta luettuun Laestadiuksen saarnaan. Myös muiden sanaelementtien merkittävyyttä seuratilanteen annissa korostetaan eräässä aineiston saarnassa luettelemalla virret, rukoukset ja ennen puhetta luettu Laestadiuksen saarna Jumalan sanan lähteinä:

Esimerkki 1: Tässäkin seuratilaisuudessa meille on jo kylvetty sanaa, kun olemme yhtyneet yhdessä laulamaan virsiä, olemme yhtyneet rukoukseen ja olemme kuulleet myöskin Laestadiuksen saarnan, jossa hän käsitteli sitä ensi kristillisyyttä, apostolista kristillisyyttä kun Jeesus oli seurakuntansa perustanut. S1

Myös seuratilanteen nonverbaaliset elementit tukevat maallikkosaarnaajan viestiä. Saarnaajalle on seuratilanteessa pedattu valmis paikka puhua: hänet kutsutaan pitämään saarnaa, hänellä on tietty istuinpaikka rukoushuoneen etuosan korokkeella, puhujanpöydän takana. Puhetilanne osoittaa myös saarnaajakollegoiden tukea puhujalle: hän ei juuri koskaan istu yksin puhujien korokkeella. Rukoushuoneiden puhujankorokkeilla on useita istumapaikkoja, joissa istuu varsinaisen puhujan lisäksi yleensä virsilaulun johtaja sekä ainakin yksi toinen saarnaaja, joka lukee seurakunnalle Laestadiuksen saarnan ja puhujan valitseman tekstin Raamatusta. Aineiston saarnat ovat valtakunnallisista seuratilaisuuksista, joissa puhuvat viikonlopun aikana vuorotellen kaksi etukäteen nimettyä saarnaajaa. Tämä kaksikko istuu vieretysten saarnapöydän takana seurojen ajan, vaikka vain toinen puhuu. Tämän lisäksi on tapana, että kaikki tilaisuudessa läsnä olevat, saarnaajan tehtävään nimetyt miehet istuvat eturivissä, saarnapöydän lähettyvillä. Tällainen asetelma antaa kuulijalle vaikutelman, että puhujan lisäksi jokainen muukin ympärillä oleva saarnaaja on tilaisuudessa puhuttujen sanojen takana ja voisi puuttua puheeseen, jos se poikkeaisi liiaksi opillisissa kysymyksissä yhteisön jaetuista näkemyksistä.

Kuulijat ja heidän suhteensa puhujaan, aiheeseen ja toisiinsa muodostavat keskeisen retorisen tilanteen osatekijän. Seuratilanteessa yleisö ja puhujat kuuluvat samaan ryhmään ja tuntevat viiteryhmänsä perinteen. Puheet kohdennetaan uskoville kuulijoille, oman yhteisön jäsenille eli sisäryhmälle, eikä aineistosta löydy ainoatakaan puhuttelua, jossa tavoiteltaisiin selvästi herätysliikkeeseen kuulumattomia kuulijoita.

Toinen puheissa esiintyvä piirre, joka asemoi saarnaajan samalle puolelle kuulijoiden kanssa, on inklusiivisen eli koko kuulijakunnan ja puhujan sisäänsä sulkevan me-muodon käyttö (ks. esim. Adler 1995). Me-muodon käyttö saarnoissa on yleistä myös evankelis-luterilaisen kirkon jumalanpalveluksissa, mikä tulee esiin niin Leiberin $(2003,264)$ kuin Puronkin $(1998,26)$ kirkon saarnoja erittelevissä tutkimuksissa. 
Leiber (2003, 30-31) näkee me-muodon käytön saarnapuheissa yhtenä strategiana suojata kuulijan kasvoja: sillä osoitetaan sosiaalisen suhteen symmetriaa (ks. myös Adler 1995, 35). Sulkemalla itsensä oman saarnansa puhuttelun piiriin saarnaaja korostaa ihmisten tasa-arvoisuutta Jumalan edessä, jolloin kuulijan on helpompi vastaanottaa itseensä kohdistuvia kysymyksiä, neuvoja tai muita puheen osia, jotka kuulija voi tulkita kasvojaan uhkaaviksi tekijöiksi (vrt. Lampinen 1990, 182). Esikoislestadiolaisissa saarnoissa kuuluvassa, ihmisen heikkoutta korostavassa opetuksessa voitaisiin puhuja tulkita jopa ylimieliseksi, jos tämä asettaisi itsensä, kuulijoista erottaen, jonkin inhimillisen heikkouden yläpuolelle.

Saarnaaja on samanaikaisesti yksi seurakuntalainen muiden joukossa, virkansa puolesta seurakunnan johtohahmoja sekä "sananpalvelija" eli seurakunnan palveluksessa puhujan tehtävässä, kuten esimerkki 2 osoittaa

Esimerkki 2: Joku saattaa ajatella niin, kyllä sentään noilla saarnaajilla menee hyvin. Ei, me olemme aivan samanlaisia. Monta kertaa tulee mieleen, saanko minä tämmöisenä uskoa. En kulje lauman edellä, vaan täytyy aivan samalla lailla kuin sanoo rovasti Laestadius: "Minun täytyy lauman jäljessä kulkea". S5

Analysoiduissa esikoislestadiolaisissa saarnoissa minimointipuhe on tyypillisempää saarnojen alkupuolella, mutta sitä esiintyy saarnojen myöhemmissäkin osuuksissa (saarnojen erilaisista aloitustyypeistä ks. Suojanen 1972, 159). Minimointipuhe on Suojasen $(1988,56)$ mukaan tyypillistä maallikoiden pitämille saarnoille, mutta ei niinkään pappien puheille. Hän arvelee, että minimointi on tapa tuoda esiin nöyryyttä kristillisenä hyveenä ja keino alleviivata saarnaajan roolia välikappaleena. Ihmisen roolin pienentämiseen liittynee osaltaan myös se, etteivät puhujat kirjoita saarnoja etukäteen vaan haluavat jättäytyä Pyhän Hengen ohjattaviksi puhetilanteessa.

Saarna-aineistosta löytyi ääneen lausuttuja toteamuksia edellä kuvatusta ihmisen roolin vähäisestä merkityksestä Jumalaan ja Raamatun sanaan verrattuna. Saarnaajat painottavat, että Raamatun teksti toimii puheen johtolankana ja seurakunnalta pyydetään sen puolesta rukoilemista, että saarnaaja voisi välittää oikein Jumalan tahdon mukaista puhetta. Esimerkeissä 3 ja 4 todetaan erityisen painokkaasti, että puhujalta itseltään ei ole odotettavissa sisältöä puheeseen, vaan Raamatun tekstiä selitettäessä "kaikki jää siihen, mitä Jumala kirkastaa" eli saarnaaja kykenee puhumaan oikein vain "jos Jumala antaa jotakin" puhetta.

Esimerkki 3: Rukoilkaa tänä päivänä Jumalaa, niin kuin niin monta kertaa minun edestäni, että Jumala kirkastaisi, mitä puhua. Kaikki jää siihen, mitä Jumala kirkastaa. S5 
Esimerkki 4: Otamme täältä Vanhan Testamentin puolelta, profeetta Jesajan kirjasta kirjoitettua Jumalan sanaa, ja puhumme ja puhun sen rinnalla jos Jumala antaa jotakin. S4

Seuratilaisuus on tässä selväpiirteinen rajaus retorisen tilanteen analysointia varten, onhan se konkreettinen tilanne, johon tullaan erityisesti kuuntelemaan puheita. Sillä on selkeä alku ja loppu ja toiminnan muoto. Kuitenkin tilanteen rajaaminen myös toisin, puheen katsominen joko lähempää tai etäämmältä on valaisevaa. Maallikkosaarnan ja sen funktioiden ymmärtämisen kannalta lienee erityisen tärkeää ottaa huomioon liikkeen perinne kontekstina. Seurat ovat muotoutuneet ajan kuluessa pienimuotoisista, kodeissa pidettävistä rukouskokouksista äärimmillään jopa tuhansien kuulijoiden yleisötilaisuuksiksi, joille on kehittynyt lähes yhtä selkeä ja muodollinen kaava kuin esimerkiksi evankelisluterilaisen kirkon jumalanpalveluksille.

Vaikka herätysliikkeen toiminta tiivistyykin seuroissa, seurakokoukset eivät ole vain jumalanpalvelusten ja kristillisen opetuksen jatkumo. Seurat ovat myös kannanottojen areena, sosiaalisen kohtaamisen ja yhteisön ylläpidon ympäristö. Vaikka maallikkosaarnaaja ei yleensä joudu kohtaamaan varsinaisia retorisia ongelmia yleisön myötämielisyysoletuksen vuoksi, yhteisön tasolla tällaisen tilanteen voisi kuitenkin ajatella muodostuvan, jos saarnoissa esiintyy toisistaan poikkeavia kannanottoja joko opetuksen tai traditioihin liittyvien asioiden suhteen. Tällaisiin ristiriitoihin viittaa esimerkiksi Blom (2001) esikoislestadiolaisuuden saarnojen opillisia näkemyksiä käsittelevässä tutkimuksessaan. Ihonen $(2001,162)$ on todennut, että "ominaista on ollut johtavienkin saarnaajien melko suuri itsenäisyys opillisten näkemysten muotoiluissa, mikä puolestaan on johtanut melkoiseen kirjoon esimerkiksi kastetta ja ehtoollista koskevissa peruskäsityksissä."

Seuratapahtuman ja herätysliikkeen muun toiminnan taustana, laajempana retorisena tilanteena on yhteiskunnallinen tilanne, joka edustaa sekä puhujan että kuulijan jokapäiväistä elämää ja josta nousevat ne ajankohtaiset teemat ja haasteet, joihin saarnoissa on vastattava. Kakkuri-Knuuttila $(1998,235)$ toteaa, että retoristen tilanteiden muutokset kertovat yhteiskunnan muutoksesta. Seuroissa pidettävien saarnapuheiden rooli on kuitenkin hyvin selvästi uskonnollisiin teemoihin keskittyvä: aineiston viidestä saarnasta ei löydy yhtäkään viittausta johonkin yksilöitävissä olevaan yhteiskunnalliseen tapahtumaan. Pelkän tekstisisältönsä perusteella näitä saarnoja ei siis voisi sijoittaa tiettyyn aikaan ja paikkaan. Ajankohtaisista tapahtumista tai uutisotsikoista ainoastaan hätkähdyttävimmät nousevat saarnojen ainekseksi. Tällaisia ovat viime vuosien aikana olleet esimerkiksi joulupäivän 2004 tsunami ja Jokelan koulusurmat syksyllä 2007. 


\section{Puheen jäsentely ja retoriset tehokeinot}

Kuten useimmiten kristillisen saarnan tapauksessa, myös esikoislestadiolaisten saarnat rakentuvat Raamatusta poimitun katkelman ympärille. Saarnojen spontaaniudesta ja puhekielenomaisuudesta huolimatta aineiston viiden saarnan rakenteessa oli joitakin tyypillisiä piirteitä. Saarnat ovat pitkiä ja polveilevia, kuulijat ovat tottuneet niiden muotoon ja antavat puhujalle ajan ja tilan puheeseen.

Puheista erottui kolme samantyyppistä jaksoa: lyhyt alkupuhe, varsinainen raamatunselitysosio sekä lopetusjakso. Puheiden aloituksissa on näkyvimmin esillä saarnojen funktio yhteisönrakennuspuheena, niissä kerrotaan usein terveisiä muilta paikkakunnilta. Saarnojen alkupuolella puhujat pohtivat myös runsaimmin omaa rooliaan ja tehtäväänsä ja esittävät pyyntöjä seurakunnan rukouksista valmistautuessaan varsinaiseen Raamatun tekstin selitykseen. Kestoltaan pisin osa kaikissa aineiston saarnoissa muodostui keskiosasta, jonka aloitukseksi luetaan puhujan valitsema teksti Raamatusta. Puhetta rytmittää palaaminen saarnatekstiin ja spontaani puheosio tekstin pohjalta. Saarnojen loppuosa puolestaan muodostuu kaikissa aineiston saarnoissa synninpäästöstä liikkeen perinteen mukaisten sanontatapojen mukaan.

Retoriset tehokeinot ovat sanottavan muovailemista sellaiseen muotoon, että yleisö kuulee asiat puhujan toivomin korostuksin. Ne ovat puhujan valintoja, joilla voi esimerkiksi vaikuttaa kuulijaan ja tehostaa ilmaisuaan, painottaa haluamiaan asioita ja herättää tarpeen vaatiessa tunnereaktioita. Tiiviin yhteisön tilaisuuksissa pidettyjen saarnapuheiden retoristen erityispiirteiden analysointi on merkityksellistä paitsi puhujan, myös koko yhteisön ymmärtämisen näkökulmasta. Tätä yhteisöjen puhekäytäntöjen näkökulmaa korostaa myös Leiber (2003, 42): hän pitää analyysia keinona tehdä näkyväksi kielenkäyttöä, joka on ajan kuluessa luonnollistunut niin, että merkityksiä ei enää tiedosteta. Osaltaan yhteisön erityisen kielenkäytön tarkoituksena on myös yhteisöllisyyden rakentaminen oman sisäryhmän kesken, ryhmän ulkopuolisista erottautuminen keskinäisen samankaltaisuuden kautta. (Yhteisön rakentamisesta kielen avulla ks. esim. Ihonen 1997; Kinnunen 2004; Leiber 2003; Suojanen 1988.)

Saarnojen tutkijat esittelevät useita, keskenään hyvin samankaltaisia jaotteluja puheen tehokeinoista. (Ks. esim. Jolkkonen 2001; Kennedy 1999; Kujanpää 1997.) Seuraavassa tarkastelemme aineistossamme yleisimmin ilmeneviä tehokeinoja: sitaatteja, retorisia kysymyksiä, toistoja, vastakkainasetteluja ja kielikuvia. Lisäksi pohditaan retorisen tehokeinon näkökulmasta niin sanotun "kaanaan kielen" eli vanhahtavan uskonnollisen kielen käyttöä, sillä se näyttäytyy saarnoissa olennaisena ja persoonallisena piirteenä.

Saarnoissa yleinen tehokeino on Laestadiuksen ja saarnaajakollegoiden puheisiin viittaaminen. Kuulijakunnan huomioon ottaen voimme verrata viit-tauksia tunnettujen lauseiden ja sitaattien käyttöön, sillä tiivis perinneyhteisö jakaa tiedon historiastaan ja sekä nyt että aiemmin vaikuttaneista puhujista. Arvostettuja saarnaajia siteeraamalla puhuja saa heidän arvovaltansa tukea omalle argumentoinnilleen, mikä tekee viittauksista toimivan retorisen tehokeinon. 
Raamattu on saarnojen ydin, se on kristinuskon opin pyhä teksti, jossa katsotaan olevan ilmoitettuna Jumalan tahto. Raamattu on kokoelma niistä perusväittämistä, jotka riittävät saarnapuheessa kantamaan argumentoinnin pelkällä olemassaolollaan. Niitä ei sellaisinaan ole tarpeen kyseenalaistaa, vaan puhuja voi olettaa kuulijoiden jakavan ne kanssaan. Puheissa käytetyt lainaukset Laestadiuksen saarnoista osoittavat herätysliikkeen perustajan sanoilla olevan samantapaisen arvovallan: niihin viittaaminen ja niiden lausuminen riittää perusteluksi, lainaukset eivät enää tarvitse nykypuhujan lisäargumentteja tuekseen (esimerkki 5).

Esimerkki 5: Onneksi me voimme hakea siihen vastauksen tuolta rovasti Laestadiukselta, joka opettaa ja muistuttaa meitä, että mihin elämänparannus kuuluu. S2

Varsinaisen saarnatekstin ohella aineiston spontaanit saarnat sisälsivät runsaasti ulkomuistista tehtyjä viittauksia myös muihin Raamatun teksteihin, ja viittausten esittelyn tavasta käy ilmi puhujan oletus sisäryhmäkuuntelijasta, jolle kristillinen, ellei lestadiolainenkin, perinne on tuttua (ks. myös Suojanen 1972).

Vastakkainasetteluiden teho retorisena tehokeinona puolestaan perustuu inhimillisen ajattelun kategorisoinnin tarpeeseen: hahmotamme asioita asettamalla ne keskinäiseen suhteeseensa vastakkainasettelun kautta.

Esimerkki 6: tuolta ristiltä ei tule mitään koston ääntä, sieltä ei tule mitään tuomitsevaa sanaa meille mutta sieltä tulee anteeksiantamuksen ihana sana. $\mathrm{S} 1$

Saarnapuheessa käytetään usein melko mustavalkoistakin hyvä-paha-asetelmaa tai toisinaan hieman haastavampaa kahden hyvän tai kahden pahan arvon vastakkain asettamista. Antiteesit ovat tehokkaita puheen terävöittäjiä ja havainnollistajia, mutta niiden runsas käyttö voi antaa myös liiallisen jyrkkyyden ja ylimielisyyden vaikutelman. (Jolkkonen 2001, 194-197.)

Analysoiduista saarnoista erottuu kaikkiaan 45 antiteesiasetelmaa. Vastakkainasetelmien avulla 1) kuvataan elämää, 2) "oikein uskovia" ja 3) havainnollistetaan opetusta ja avataan kielikuvia. Kun vastakkainasetteluja käytetään kuvaamaan elämää maailmassa (myrskyt, kiusaukset), elämää verrataan toisaalta tulevaisuuteen taivaassa (tyyni, hiljainen) tai seuratilaisuuksien suomaan "lepohetkeen" elämässä (vapaus). Tämä piirre korostuu saarnojen alussa, seuratilanteesta puhuttaessa sekä loppupuolella, toivoa luovissa loppulauseissa.

Esimerkki 7: Me joudumme täällä elämään monenlaisten myrskyjen alla, mutta sen voin sanoa, kuulkaa ystävät, kotirannalla on pieni, hiljainen, tyyni paikka. S5

"Oikein uskovien" ihmisten elämäntapojen, -arvojen ja -sisällön erottelemisessa "ei-uskovien" elämästä, tai oikein uskomisen erottamisessa väärin uskomisesta, voidaan nähdä Burken (Adlerin 1995, 36-37 mukaan Burke 1973, 271) esittämä 
antiteesien funktio: uskonnollisten yhteisöjen tarve kehittää identiteettiään vastakohtien kautta, erottautumalla jostakin muusta aatteesta. Näissäkin saarnoissa pyritään vastakkainasetteluilla erottautumaan siitä seurakuntayhteisön ulkopuolisesta elämästä, mitä kutsutaan kaikenkattavasti "maailmaksi" tai toisaalta "kuolleesta uskosta" (esimerkki 8).

Esimerkki 8: Me tiedämme, että kuollut usko ei ole yhtään mitään. Kuolleella uskolla ei taistella vihollista vastaan. Mutta elävä usko, Jumalan antama usko, jossa on voima syntiä ja kaikkea saastaisuutta vastaan, ainoastaan se antaa meille voiman sotimaan. S2

Esimerkin 8 elävän ja kuolleen uskon erottelu toisistaan limittyy jo seuraavan, eniten esiintyvän antiteesin käyttötavan kanssa. Yleisin funktio antiteeseillä näyttää saarna-aineistossa olevan opetuksen havainnollistaminen ja kielikuvien avaaminen - raamattuopetuksen ja sen tekstien havainnollistamisen osuus saarnoista onkin suuri. Toisaalta tämän antiteesin määrittely on vaikeimmin rajattavissa ja siihen solahtaa keskenään melko erilaisiakin antiteesin käyttämisen tapauksia. Esimerkit 9 ja 10 painottavat saarnojen opetusnäkökulman kannalta merkittäviä teemoja, niistä viimeisessä selvennetään myös valitusta saarnatekstistä löytyvän antiteesiasetelman hengellistä merkitystä. Jylhä ja korkea Siinain vuori on Jumalan lain vertauskuva, pieni ja rauhallinen Siionin vuori puolestaan kuvaa Kristuksen seurakuntaa, uskovien yhteisöä.

Esimerkki 9: Kaikki on siitä, että Jumala on sytyttänyt sydämissämme elävän uskon. Hän ei sytytä sitä katumattomaan sydämeen, mutta katuvaiseen ja armoa anovaan sydämeen. S4

Esimerkki 10: Siellä Siinain vuori siellä Jerusalemissa ulottuu satoja kilometrejä aina Aasiasta Jerusalemiin saakka. Se on jylhä ja korkea vuori. Sillä kuvataan Hagaria eli Jumalan lakia. Se näyttää aivan ylitsepääsemättömältä. Kun sen sijaan tuo Siionin vuori siellä Jerusalemissa, jolla kuvataan Kristuksen seurakuntaa täällä maan päällä, se on pieni ja rauhallinen kukkula. S3

Retorinen kysymys toimii niiden kohtien merkitsijänä, joita puhuja haluaa erityisesti painottaa, ja vaikka ääneen lausuttua vastausta ei odotetakaan, näillä kysymyksillä voidaan myös pitää yllä kontaktia kuulijoihin ja herätellä heitä ajattelemaan puheen teemoja. Retoristen kysymysten käyttö saarnojen tehokeinona on tavallista. Niin Puro $(1998,39-41)$ kuin Leiberkin $(2003,150)$ toteavat, että papit käyttävät niitä runsaasti puheessaan. Kujanpää $(1997,379)$ on laskenut Laestadiuksen saarnoissa olevan keskimäärin seitsemän kysymystä kussakin. Myös analysoiduissa saarnoissa kysymyksiä on runsaasti, yhteensä 60 kappaletta. Kysymyksistä vain yksi on vastausta vaativa, sillä saarnaaja kohdisti sen 
eksplisiittisesti toisille paikalla oleville saarnaajille. Kaikkien muiden kysymysten voi siis ajatella olevan puheen tekniikkaa ennemmin kuin todellista keskustelua kuulijoiden kanssa.

Kaikissa puheissa esiintyi retorisia kysymyksiä, mutta niiden määrä vaihteli 5:stä 20:een. Kaksi eniten retorista kysymystä käyttänyttä puhujaa ovat rytmittäneet saarnansa ja varsinkin sen sananselitysosan jaksoiksi kysymysten avulla. Samankaltaisen havainnon teki myös Puro $(1998,39)$ evankelis-luterilaisen kirkon pappien saarnoja kuvatessaan: noin puolet hänen aineistonsa saarnoista etenivät kysymys-vastaus-jaksojen avulla lähes alusta loppuun.

Analysoitujen saarnojen lukuisille kysymyksille hahmottuu kolme pääasiallista käyttötapaa. Retoristen kysymysten avulla

1) kuvataan ja kumotaan uskoon liittyviä epäilyjä ja epävarmuuksia (ks. esimerkki 11)

2) painotetaan opetukseen liittyviä väitelauseita (ks. esimerkki 12)

3) ja niitä myös käytetään kysymyksen muotoon puettuina kehotuksina (ks. esimerkki 13).

Esimerkki 11: "Sitä minä rakastan, että Herra kuulee minun rukoukseni äänen." Kuinka on, kristityt, kuuleeko Jumala aina meidän äänemme? Kyllä hän kuulee. S5

Esimerkki 12: Mitä eroa on sitten tuon Saaran pojalla ja Haagarin pojalla? Perintöosa on erona. Tuolla piian lapsella ei ole perintöosaa ollenkaan, kun sen sijaan Saaran lapsella on. [...] Tottahan me haluaisimme sen paikan siellä taivaassa. Se on se perintöosa. S3

Esimerkki 13: Kuinka nyt on sinun ja minun kanssani tänä iltana ja tänä aikana? Jaksammeko me näin paljon huolehtia niistä kristityistä, joita me emme tunne? Me saamme sitä tutkia itse kukin omassa sydämessämme.S2

Toisto on tehokas retorinen keino, sen avulla voi nostaa esiin keskeisiä asioita ja herättää tunteita kuulijoissa. Toiston teho perustuu kahteen periaatteeseen: toistettu asia on tärkeä ja toistettu asia on totta. Puhujan on toisaalta syytä olla varovainen käyttäessään runsaasti toistoa puheessaan, sillä liiallinen toistaminen voi kuulostaa koomiselta ja näin horjuttaa puhujan uskottavuutta. (Jolkkonen 2001, 192; Kakkuri-Knuuttila 1998, 238.)

Suojanen $(1988,60)$ mainitsee tutkimiensa maallikkosaarnojen sisältävän paljon toistoa, sillä ennalta kirjoittamattomina niissä on puhekielen piirteitä, ja puhekieli on usein melko toisteista. Hän toteaa myös, että toistoton saarnapuhe on "nollainformaatiota": vain kertaalleen mainittu asia jää helposti kuulijalta huomioimatta. Aineiston saarnoissa on erittäin paljon toistoa eri tavoin käytet- 
tynä. Niistä voitiin rajata yhteensä 36 toistorakennetta, joista useat olivat vieläpä melko pitkiä, joten suuri osa saarnojen tekstimassasta on varsin toisteista.

Esimerkissä 14 painotetaan viestiä toistamalla sanoja "ei ole mitään muuta ...". Toisto ei näissä spontaaneissa saarnoissa ole ainoastaan puhekielisyyttä ja keino olla katkaisematta puhetta ajatuksen jatkoa etsittäessä, vaan asian esiin tuomista tehostamaan valittu retorinen tehokeino.

Esimerkki 14: Ei ole mitään muuta pysyvää kuin jumalan sana. Ei ole mitään muuta joka pitää elämässä kuin ainoastaan jumalan sana. Ei ole mitään muuta joka pelastaa iankaikkisesta onnettomuudesta kuin usko jumalan sanaan, siihen sanaan, joka on kerran tullut ihmiseksi eli lihaksi tähän maailmaan. S2

Kielikuviin kuuluvat metaforat ja vertaukset. Metafora on perinteisen määritelmän mukaan vertaus ilman kuin-sanaa, vertauksen olemassaoloa ei siis eksplikoida vaan jätetään se kuulijan ymmärrettäväksi (Kakkuri-Knuuttila 1998, 259). Tässä käsitellään kielikuvia yleisesti, sen teemoja ja käyttötapoja.

Aristotelen $(1997,226)$ Retoriikan ja Runousopin suomennoksen selityksissä Juha Sihvola kokoaa Aristoteleen ajatuksista kielikuville neljä tehtävää: ne elävöittävät esitystä, havainnollistavat ja selventävät asiaa, ohjaavat tunteita siirtämällä ilmaisun sisältämän emotionaalisen sisällön kohteesta toiseen ja voivat ilmaista sellaisia asioita, joilla ei ole nimeä. Analysoiduissa saarnoissa kuvakieltä käytetään enimmäkseen elävöittämiseen ja havainnollistamiseen. Muotoilu on usein metaforan määritelmän kaltaista: puhujat näyttävät olettavan, että kuulijat tuntevat ja ymmärtävät puheiden kuvakielen ilman alleviivaamista ja auki selittämistä. Myös kuvakielen merkitysten selittämistä opetuksenomaisesti kuitenkin esiintyy, kuten esimerkissä 10. Siinä saarnaaja toteaa Siinain vuoren ja Siionin vuoren erot ja mainitsee, mitä kullakin kuvataan.

Esimerkki 15: Mutta hän antoi myöskin ihanan lupauksen pojastaan Jeesuksesta Kristuksesta, että vaimon siemen on rikki polkeva käärmeen pään. Ja kun aika oli täyttynyt niin tuo lupaus täyttyi, ja Jeesus tuli, eli liha tuli sanaksi meidän keskuudessamme ja tuo Jumalan poika täytti meidän puolestamme Jumalan tahdon eli Jumalan lain täydellisesti. S1

Puhujan oletus kuulijoiden Raamatun ja kristillisen perinteen tuntemuksesta tulee esille käsitteiden ja sanontojen tasolla. Saarnaajat poimivat niitä teksteistä ja vanhoista saarnoista puheisiinsa, eivätkä useinkaan avaa niiden merkityksiä, kuten esimerkissä 15: "vaimon siemen on rikki polkeva käärmeen pään" on lausahdus Raamatusta (1. Moos. 3:15), ja se jätetään sen tarkemmitta täsmennyksittä. Kuvakielen luonnollistumisesta osaksi saarnapuhetta voi päätellä jälleen saarnaajien kohdistavan puheensa yhteisön jäsenille, sisäryhmälle, jolle ei tarvitse kerta kerran jälkeen avata tutuimpien vertauksien merkityksiä. 
Täsmällisiä, yksittäisiä kielikuvia saarnoista on vaikea erotella ja laskea ennemminkin voisi puhua kuvakielellä saarnaamisesta. Saarnoista on kuitenkin poimittu vertauskuvallisia jaksoja, jotta niiden käytön tapa ja runsaus eri puhujilla selkiytyisi. Kaiken kaikkiaan vertauskuvallista puhetta on saarnoissa hyvin paljon, kaikkiaan 39 sellaista tekstijaksoa, joissa puhe etenee kuvakielellä. Runsasta kuvakielellä saarnaamista havainnollistaa pitkähkö katkelma eräästä saarnasta: saarnaaja etenee sujuvasti kylvämisen ja kastamisen vertauskuvista vaeltamisen kautta rakentamiseen:

Esimerkki 16: Apostoli käyttää niin kovia sanoja ja sanoo, että te olette kaikki vielä lihallisia, kun te niin ajattelette. Ja muistuttaa, että ihminen vain kylvää ja kastaa mutta Jumala antaa kasvun. Se, että me olemme juurtuneina Jeesukseen Kristukseen, tuohon elämänpuuhun, joka tarkoittaa sitä, että meillä on elävä usko, silloin me pysymme elossa ja me myöskin saamme voimaa vaellukseen ja kulkemiseen tämän maan päällä. Kuinkahan paljon sitten meidän pitää jaksaa uskoa? Muistan, kuinka aina ovat saarnaajat meitä tässä kohdassa niin opettaneet, että meidän tulee uskoa iloon ja rakkauteen saakka. Uskon, että me näin pitkälle olemme myöskin uskonelämässämme päässeet, että me olemme saaneet maistaa sitä, mistä Raamattu puhuu: että Herra on suloinen. Tässä puhutaan myöskin vielä rakentamisesta. Olemmehan me aivan vakuutetut ja varmat siitä, että meillä on rakennettu kristillisyys? S2

Raamatun teksteissä on paljon vertauskuvallisuutta, joten niiden runsas määrä sen tekstien selitykseen perustuvissa saarnoissa on luontevaa: Raamattua selitettäessä pyritään välittämään kuulijoille sellaisia kokemuksia ja tuntemuksia, jotka auttavat ymmärtämään kauan sitten kirjoitettua tekstiä. (Lampinen 1990, 157.) Arnett (1998) pohtii metaforien toimivuutta uskonnollisessa kielessä ja painottaa, että olennaisinta on yhdistää uskonnollinen kertomus kulloiseenkin historialliseen ajanhetkeen. Hän toteaakin, että yleensä saarnoissa käytetyn kuvakielen pitäisi muuttua, jotta tämä yhdistäminen onnistuisi. Puhujien olisi käytettävä metaforia, jotka "marssivat meneillään oleviin elämän tapahtumiin". Näin metaforat voisivat vastata kuulijoiden todellisuutta. (Arnett 1998, 141144.) Esikoislestadiolaisten saarnapuheiden kielikuvat eivät kuitenkaan ole ajan mittaan muuttuneet, ja silti kuulijat istahtavat penkkeihin kerta kerran jälkeen. Kenties tässä tapauksessa muuttumattomuus on kääntynyt tavoiteltavaksi piirteeksi, joka sopii perinnettä arvostavalle yhteisölle.

Yhteisön, tässä tapauksessa esikoislestadiolaisuuden, jäsenyys, kristinuskon kuvasto sekä sen representaatiot oman yhteisön perinteessä vaikuttavat puheessa käytettyjen kielikuvien valintaan ja ymmärtämiseen (ks. Arnett 1998). Saarna-aineiston kielikuvat ovatkin kautta linjan Raamatusta poimittuja ja hyvin perinteisiä aina sanavalintoja myöten. Esikoislestadiolaisten maallikko- 
saarnojen omintakeinen piirre onkin tiukasti Raamatun vertauskielessä pysytteleminen, nykyaikaisesta elämästämme poimittuja kielikuvia ei saarnoissa kuulu, toisin kuin monien muiden uskonnollisten yhteisöjen puheissa (vrt. esim. Cabot 2005, 291).

Esikoislestadiolaisissa maallikkosaarnoissa säilyvät perinteiset kristillisen uskonnollisen puheen teemat, jopa hieman vanhahtavassa muodossa. Vaikka kielikuvien sisältö nouseekin melko ajattomista teemoista, kuten maanviljelystä, vaeltamisesta ja sotimisesta, niiden esittämisen muoto voisi tehdä niistä hieman vaikeasti ymmärrettäviä kuulijoille, jotka eivät ole tottuneet herätysliikkeen perinteiseen puhetapaan. Jotta kielikuva toimisi havainnollistamisen ja tunteiden herättämisen välineenä hyvin, puhujan ja kuulijoiden pitää ymmärtää se samalla tavalla. Saarnojen kuvakieleen tottuminen on siis ikään kuin yhteisön kielen oppimista, eräs piirre, johon kasvetaan liikkeen sisällä elettäessä tai askel kohti yhteisön täysvaltaista jäsenyyttä sitä ulkopuolelta lähestyttäessä.

Suojanen $(1988,53)$ kuvailee tutkimiensa herätysliikesaarnojen kieltä puhekielisten piirteiden ja murteiden sekä Raamatusta ja muista uskonnollisista teksteistä ammennetun kielen yhteensulautumaksi. Tämä pätee osin myös esikoislestadiolaisiin saarnoihin. Niiden kieli on melko huoliteltua, vahvoista murreilmaisuista vapaata yleiskieltä, jota persoonalliset "kaanaan kielen" ilmaisut sävyttävät. Nimitystä "kaanaan kieli" käytetään monissa eri uskonnollisissa yhteisöissä kristillisestä "sisäpiirikielestä", joka tarkoittaa enimmäkseen vanhoista raamatunkäännöksistä poimittuja sanoja, sanontoja ja muita puhetyylin piirteitä - osa metaforistakin sopii tähän luokkaan. Tässä "kaanaan kieltä" käsitellään puheiden retorisena tehokeinona, sivuten samalla saarnojen kielenkäyttöä kokonaisuudessaan.

Esimerkki 17: Mutta ajattelen niin omastakin kokemuksesta, että me sittenkin kristittyinä tarvitsemme rakentua monella tavalla. S2

\section{Esimerkki 18: Olkoon vielä kaunista meidän seurustelu toistemme kanssa. S5}

"Kaanaan kielen" piiriin kuuluvaksi voidaan lukea myös mainittujen vanhoista teksteistä poimittujen sanontojen lisäksi myös esimerkiksi erikoisen sanajärjestyksen (esimerkit 17 ja18) käytön. Saarnojen tavallisesta puhekielestä poikkeavien piirteiden syitä voisi mahdollisesti etsiä vanhan kirkkoraamatun ja muiden vanhanaikaisella kielellä kirjoitettujen tekstien lukemisen sekä liikkeessä vahvasti läsnä olevan ruotsin kielen vaikutuksesta. "kaanaan kieli" kuuluu vahvasti myös liikkeen perinteisten hengellisten laulujen sisällöissä. Sanasto liikkuu perinteisen hengellisen ja melko muodollisen kielenkäytön alueilla kaikissa aineiston saarnoissa. Leiber $(2003,250)$ ja Antola (2009) ilmaisevat täysin päinvastaisen havainnon kirkon saarnojen osalta tämän vuosituhannen alusta todetessaan, että papit pyrkivät herättämään kuulijoiden mielenkiinnon tuomalla 
uusia, traditioon nähden rohkeita ilmaisuja saarnadiskurssin käyttöön. Evankelis-luterilaisen kirkon saarnaoppaissa ja esimerkiksi Suojasen kirjoituksissa saarnapuheesta "kaanaan kieltä" pidetäänkin halventavana nimityksenä, joka kuvaa epäselvää, vanhahtavaa kielenkäyttöä, josta pitäisi pyrkiä eroon. Herätysliikekontekstissa "kaanaan kielellä" on mitä ilmeisimmin parempi kaiku, tuttuuden ja turvallisuuden tae.

Esikoislestadiolaiset maallikkosaarnaajat eivät saarnoissaan selitä vanhanaikaisia sanontoja, vaan luottavat selvästi siihen, että kuulijakunta ymmärtää heidän käyttämäänsä kieltä. Ihonen $(1997,97)$ toteaa, että tällainen ulkopuolisille avautumaton puhe- ja ajattelutapa on tärkeä niille liikkeille, jotka pitävät omaleimaisen identiteetin ylläpitämistä tärkeänä. Leiber (2003, 63) puolestaan nimittää "hyrinäkieleksi” ja Suojanen $(1988,45)$ "kyhnytyspuheeksi" rituaalistunutta, uskonnollista kieltä, jonka sanojakaan kuulija ei välttämättä ymmärrä. Tällä puheella, joka on herätysliikkeen historian aikana muovautunut eräänlaiseksi "saarnakoodiksi", on kuitenkin vaikutus kuulijoihin: se luo oikean tunnelman tilaisuuteen, antaa tunnekokemuksia, vahvistaa yhteenkuuluvuutta ja luo turvallisuutta. (Leiber 2003, 63; Kinnunen 2004, 31; Suojanen 1988, 45.) Ihonen (2001) esittääkin, että uskonnollista kieltä ei tohdita lähteä muuttamaan, koska koetaan asiasisällöt niin pyhiksi, ettei muotoonkaan voi koskea. Raamatun sanoman ajatellaan olevan tavoitettavissa parhaiten sillä kielellä, millä ennenkin. Vanhanaikaisesta kielestä kiinni pitäminen sopii hyvin kuvaan muutoinkin uudistusvastamielisestä esikoislestadiolaisesta herätysliikkeestä. Perinteisyyttä arvostavat kuulijat voisivat tuntea turvattomuutta, jos tutuista asioista alettaisiin puhua liian modernein termein - kieliihän tästä myös vanhojen raamatunkäännösten käyttö.

\section{Saarna ja tilanne retorisena kokonaisuutena}

Eräs tapa lähestyä puheiden retorista kokonaisuutta on pohtia, miten ne vastaavat kunkin puhetilanteen erityisvaatimuksiin. Spontaaniudestaan huolimatta saarnapuheen muodot ja sisällöt ovat melko tarkkaan normitettuja, ja saarnaajien on täytynyt oppia nämä normit jo ennen kuin heidät on valittu tehtävään, ovathan he silloin olleet yhteisön jäseniä jo kauan ja kuulleet runsain mitoin hyväksyttyjen saarnojen malleja. Normeissa pysymällä saarnaaja pystyy vastaamaan perinneyhteisön jäsenkuulijoiden vaatimuksiin lähes aina, poikkeuksia saattaa asettaa ennemminkin kuohunta retorisen tilanteen uloimmissa renkaissa, esimerkiksi jokin yhteiskunnallinen kriisitilanne. Esikoislestadiolaisen seurapuheen normit vaikuttavat poikkeavan huomattavasti evankelis-luterilaisen kirkon pappien saarnoista. Puro (1998, 50-57) päätyi niitä analysoidessaan toteamaan, että papit ovat sangen varovaisia puheessaan ja käyttävät erilaisten retoristen tehokeinojen suomia mahdollisuuksia niukasti, retorisia kysymyksiä lukuun ottamatta. Aineiston viittä saarnaa ei voi kuvata niukoiksi, herätysliikkeen perinne ja kenties myös saarnojen spontaanius johtavat runsaaseen toistojen, vastakkainasettelujen ja kielikuvien käyttöön. 
Pohdittaessa puheen toimivuutta kontekstissaan keskeisintä lienee sen funktioiden määrittely. Mihin saarnapuheella ylipäätään pyritään? Suojanen $(1973,149)$ on erotellut oman aineistonsa maallikkosaarnapuheille erilaisia funktioita kuulijakunnan mukaan. Hän on jakanut kuulijat kolmeen ryhmään: ulkoryhmään, marginaaliryhmään ja sisäryhmään. Ulkoryhmään kuuluville yhteisön perinne ei ole tuttu eivätkä he myöskään usko sen oppeihin, joten heille tarjottavan saarnan tarkoituksena on evankelioida, levittää yhteisön jäsenten jakamaa oppia ja arvoja. Marginaaliryhmään kuuluvat puolestaan ne, jotka ovat jollakin tavalla kiinnittyneet herätysliikkeeseen, mutta eivät varsinaisesti allekirjoita sen oppeja. Tälle ryhmälle on tarkoitus siirtää uskonnollista traditiota saarnan avulla. Sisäryhmä muodostuu yhteisön aktiivisista jäsenistä, ja heille kohdistettu saarna on tarkoitettu ryhmän koossa pitämiseen ja myös uskonnollisen seurustelun välineeksi. (Suojanen 1973, 149.) Tässä saarna-aineistossa painottuu yhteisön jäsenille saarnaaminen.

Saarnoista piirtyi retorisen analyysin myötä esiin kuva perinneyhteisön normeissa pysyttelevästä puheesta, jolla on monia funktioita herätysliikkeen toiminnassa: seurapuheet ovat opetuksen väline, niiden tarkoitus on luoda turvallisuutta ja yhteyksiä eri paikkakuntien välille, ne ovat keskustelupuheenvuoroja yhteisön "poliittisella areenalla" ja otaksuttavasti myös yhteisön jäsenten keskustelun lähtökohtia. Saarnojen vaikutus ei siis ole ainoastaan yksittäisen saarnan yksittäisessä tilanteessa kuulijoissa aikaan saama vaikutus, vaan ennen kaikkea saarnaperinteen herätysliikettä ylläpitävä vaikutus. Näistä saarnoista voidaan todeta samoin kuin Adams ja Yarbrough $(1997,25)$ ovat kirjoittaneet vanhoista kalvinistisista saarnoista: saarnojen tarkoitus ei ole niinkään opettaa tai vakuuttaa, sillä kuulijat ovat jo oppineet ja vakuuttuneet. Saarnojen tehtävänä on ensisijaisesti muistuttaa seurakuntaa siitä, mitä he jo tietävät ja uskovat.

Retorista analyysiä yhteen vetäen saarnoista nousee esiin se, mitä seurakunta jo tietää ja uskoo. Saarnatilanteen puhuja eli lähetysmies, yksi seurakuntalaisista, on puhumisessa instrumentti, joka tulkitsee ja välittää Jumalan sanaa tai sanottavaa. Ihminen ei saa omilla ajatuksillaan ja tulkinnoillaan tulla liikaa kuulijan ja Jumalan väliin ja niinpä puhuja, saarnaaja, jopa pyytää seurakuntalaisia rukoilemaan puolestaan, että osaisi välittää sanan oikein tai hyvin. Varmistaakseen oikean paikkansa ja roolinsa välittäjänä tai välikappaleena ja korostaakseen tehtävänsä merkittävyyttä saarnaajat minimoivat puheessaan itseään tai rooliaan.

Kun Raamatun sisältö nähdään totena, argumentoitaessa ei ole tarpeen erikseen perustella otteita Raamatusta. Samantapainen arvovalta on herätysliikkeen perustaja Laestadiuksen tulkinnassa Raamatun sisällöistä. Kun Raamattu ja Laestadius asemoidaan auktoriteeteiksi ja totuuden kertojiksi, tämän päivän ihminen - puhuja ja hänen yleisönsä - asettuvat auktoriteetteihin nähden toissijaisiksi, heikommiksi ja oppiviksi oppilaiksi, lapsiksi.

Saarnaajalle annetaan saarnatilanteessa keskeinen paikka välitystehtävää varten. Hän on kuulijoiden edessä. Silti saarnakollegoiden rinnalla puhuja ei ole yksin 
ja hän on tehtäväänsä suorittamassa nimenomaan kutsuttuna, ei omasta halustaan eikä yksin sanomaa tulkiten.

Edellisen lisäksi puhujan ja kuuntelijan kuulumista samaan yhteisöön korostetaan saarnoissa eri keinoin. Saarnaaja käyttää me-muotoa ja pitäytyy niissä esitystavoissa, jotka ovat yhteisössä tunnistettuja. Erityisyys samalla yhdistää yhteisön jäseniä ja erottaa heidät yhteisön ulkopuolisista. Saarnaaja ei vaikuta niinkään kuvaavan omia erityisiä käsityksiään ja mielipiteitään kuin kertaavan yhteisön jakamia käsityksiä ja kokemuksia. Yhteisön jäsenyys korostuu myös saarnoissa luoduissa vastakkainasetteluissa, kielikuvissa ja ns. kaanaan kielessä, joiden ymmärtäminen, tulkitseminen saati tuottaminen on mahdollista vain viestintäyhteisön jäsenille.

\section{Johtopäätöksiä}

Aineiston viiden saarnan perusteella vaikuttaa siltä, että esikoislestadiolainen herätysliike edustaa nykyiselläänkin kaikkia niitä neljää roolia, jotka Huotari (1981, 168-173) herätysliikkeille kuvaili: maallikkoliikettä, perinneliikettä, viiteryhmää ja protestiliikettä. Esikoislestadiolaisuus on selvästi maallikkoliike, sillä edelleenkin kaikki sen toiminta on maallikoiden varassa ja teologisen koulutuksen saaneet puhujat ovat hyvin harvassa. Saarnaajat pysyttelevät liikkeen perinteen muovaamien puheen normien rajoissa ja korostavat oman yhteisön omintakeisuutta ja arvoa asettamalla sen vahvasti vastakkain muun maailman kanssa sekä viittaamalla usein vanhoihin, tuttuihin puhujiin. Yhteisö jakaa käsityksen Jumalan ja ihmisen suhteesta (tai erosta), ihmiskuvasta, uskonnon olemuksesta ja merkityksestä ihmiselle sekä uskosta ja uskomisesta, sen olemuksesta, vaikeudesta ja oppimisesta. Pelkkien saarnapuheiden perusteellakin voidaan siis todeta, että perinneliikkeen sekä toisaalta viiteryhmän roolit ovat selvät. Tästä toista sataa vuotta vanhasta herätysliikkeestä on kuitenkin nykyiselläänkin löydettävissä myös protestiliikkeen piirteitä: liikkeen vahva konservatiivisuus on kääntynyt suorastaan protestiksi ympäröivän yhteiskunnan muutoksia vastaan.

Liioittelematta lienee mahdollista sanoa, että seurapuheet ovat koko herätysliikeyhteisön koossa pitävä liima. Saarnat ovat polveilevia ja pursuavat Raamatusta lainattua kuvakieltä. Puheiden spontaanius ja assosiatiivisuus vie puhujaa sivupoluille, mutta saarnan ytimenä toimiva raamatunteksti palauttaa puhujan aiheeseen. Esikoislestadiolaisten maallikkosaarnojen kielessä yhdistyvät Raamatun tekstit ja Laestadiuksen saarnojen, puhujien oma tausta ja herätysliikkeen perinne (ks. Leiber 2003, 84; Suojanen 1988, 53). Saarnapuheessa useat kertomukset sekoittuvat toisiinsa, niiden intertekstuaalisuus on moniäänistä, ja toisinaan on vaikea hahmottaa, milloin sitaatit Raamatusta, Laestadiukselta tai muilta puhujilta alkavat ja loppuvat. Saarnojen analysointi pienemmistä osasista isompiin kokonaisuuksiin edeten ja kontekstin huomioon ottaminen rakensivat kaikki samansuuntaista kuvaa esikoislestadiolaisista maallikkosaarnoista: ne ovat van- 
hakantaisiin muotoihin kiinnittyneitä, omalla perinteisellä tavallaan retorisesti rikkaita, mielleyhtymien kautta Raamatun tekstejä selittäviä puheita, jotka toimivat perinneyhteisön identiteetin tukijana ja seurakuntayhteisön opettamisen ja rohkaisemisen välineinä.

\section{Kirjallisuus}

Adams, J. C. \& Yarbrough, S. R. 1997. "Sinners" in the hands of an angry God, saints in the hands of their father. Journal of Communication \& Religion 20 (1), 25-35.

Adler, B. J. 1995. Building and maintaining church identity. Rhetorical strategies found in letters from two Lutheran leaders. The Journal of Communication and Religion 18 (2), 29-39.

Antola, P. 2009. Hyvä saarna tulee lähelle kuulijan arkea. Hiidenkivi 16 (3), 36-37.

Aristoteles 1997. Retoriikka. Teokset, osa IX. Suomentajat Paavo Hohti (I-II) ja Päivi Myllykoski, selitykset Juha Silvola. Tampere: Gaudeamus.

Arnett, R. C. 1998. Interpersonal praxis. The interplay of religious narrative, historicality and metaphor. Journal of Communication and Religion 21 (2), 141-163.

Bitzer, L. F. 1968. The rhetorical situation. Philosophy and Rhetoric 1 (1), 1-14.

Blom, R. 2001. Jumalan lapseksi. Käsitys uudestisyntymisestä esikoislestadiolaisessa julistuksessa. Tampere: Kirkon tutkimuskeskus.

Burke, K. 1973. The philosophy of literary form: studies in symbolic action. Berkley: California University Press.

Cabot, M. 2005. When the trumpet call is unclear: A rhetorical analysis of the speech that launched the Jesus seminar. Journal of Communication \& Religion 28 (2), 286-306.

Carbaugh, D. 1990. Toward a perspective on cultural communication and intercultural contact. Semiotica 80 (1-2), 15-36.

Carbaugh, D. \& Wolf, K. 1999. Situating rhetoric in cultural discourses. In A. González \& D. V. Tanno (Eds.) Rhetoric in intercultural contexts. International and intercultural communication annual, Vol. 22. Beverly Hills: Sage, 19-30.

Hietanen, M. 2009. Yhteisyys ja erillisyys retorisina strategioina Nokia Mission Missio-illoissa 2009. Esitelmä Puheviestinnän päivillä Jyväskylässä 25.9.2009.

Huotari, V. 1981. Kirkkomme herätysliikkeet tänään. Helsinki: Kirjapaja.

Ihonen, M. 1997. Uskonnolliset kielipelit. Vallankäyttöä ja identiteetin vahvistamista. Teoksessa M. Mälkiä \& J. Stenvall (toim.) Kielen vallassa. Näkökulmia politiikan, uskonnon ja julkishallinnon kieleen. Tampere: Tampere University Press, 91-103.

Ihonen, M. 2001. Esimodernista myöhäismoderniin. Esikoislestadiolaisuus kohtaa nykymaailman. Teoksessa T. Eskola (toim.) Iustitia - Suomen teologisen instituutin aikakauskirja, 14. Helsinki: Suomen teologinen instituutti, 154-178. 
Jolkkonen, J. 2001. Saarnan kielellisiä tehokeinoja. Teoksessa J. Jolkkonen, S. Peura \& O. Vatanen (toim.) Saarnan käsikirja. Helsinki: Kirjapaja, 187-202.

Kakkuri-Knuuttila, M.-L. 1998. Retoriikka. Teoksessa M.-L. Kakkuri-Knuuttila (toim.) Argumentti ja kritiikki. Lukemisen, keskustelun ja vakuuttamisen taidot. Helsinki: Gaudeamus, 233-272.

Kennedy, G. 984. New Testament interpretation through rhetorical criticism. Chapell Hill: University of North Carolina Press.

Kennedy, G. 1999. Classical rhetoric \& its Christian \& secular tradition from ancient to modern times. Chapell Hill: University of North Carolina Press.

Kinnunen, M. 2004. Herätysliike kahden kulttuurin rajalla. Lestadiolaisuus Karjalassa 1870-1930. Jyväskylä Studies in Humanities 19. Jyväskylän yliopisto.

Kujanpää, L. 1997. Kristillinen saarna. Lars Levi Laestadiuksen saarnojen funktionaalis-historiallinen analyysi. Suomen ja saamen kielen ja logopedian laitoksen julkaisuja 9. Oulun yliopisto.

Lampinen, T. 1990. Yhteinen jumalanpalvelus. Käyttäytymistieteellisiä näkökulmia jumalanpalvelukseen. Vammala: Suomalaisen teologisen kirjallisuusseuran julkaisuja 166.

Leach, J. 2000. Rhetorical analysis. In M. Bauer \& G. Gaskell (Eds.) Qualitative researching with text, image and sound. London: Sage, 207-226.

Leiber, I. 2003. Ex cathedra: instituutio puhuu. Saarnan ja opetuspuheen interpersoonaisia piirteitä. Acta Universitatis Ouluensis, Series B, Humaniora 53. Oulun yliopisto.

Patton, M. Q. 2002. Qualitative research and evaluation methods. 3rd edition. Thousand Oaks: Sage.

Puro, J.-P. 1998. Retoriikasta saarnaan. Tutkimus seurakuntasaarnojen retorisesta vaikuttavuudesta. Tampere: Kirkon tutkimuskeskus.

Raittila, P. 1976. Lestadiolaisuus 1860-luvulla. Leviäminen ja yhteisönmuodostus. Helsinki: Akateeminen kustannusliike.

Raittila, P. 1984. Esikoislestadiolaisuus Suomessa. Helsinki: Suomen kirkkohistoriallisen seuran vuosikirja 74 .

Suojanen, P. 1973. Spontaani saarna. Helsinki: Finnish Society for the Study of Comparative Religion.

Suojanen, P. 1988. Ylipuhujat. Viestinnän näkökulmia uskontoon ja politiikkaan. Helsinki: Kirjapaja.

Talonen, J. 1993. Esikoislestadiolaisuus ja suomalainen yhteiskunta 1900-1944. Helsinki: Suomen kirkkohistoriallinen seura.

\section{Muut lähteet}

Biblia: Se on koko Pyhä Raamattu, 1976. Oulu: Suomen Rauhanyhdistysten keskusyhdistys.

Pyhä Raamattu, 1993. Suomen evankelis-luterilaisen kirkon kirkolliskokouksen vuonna 1992 käyttöön ottama suomennos. Pieksämäki: Kirjapaja. 